\title{
Pengaruh Perendaman Daging Sapi dengan Ekstrak Bunga Kecombrang (Etlingera elatior) terhadap Susut Masak, pH dan Organoleptik (Bau, Warna, Tekstur)
}

\author{
Effect of Marinating Beef Meat in Etlingera elatior Extract on Cooking Loss, pH, and Organoleptic \\ (Aroma, Color, and Texture)
}

\author{
D. Dina, E. Soetrisno dan Warnoto
}

Jurusan Peternakan, Fakultas Pertanian,Universitas Bengkulu Jalan W.R. Supratman, Kandang Limun, Bengkulu 38371 A

Email:desridinaptr@yahoo.com

\begin{abstract}
Meat is a food source of animal protein that is easily damaged by the activity of food-damaging microorganisms. Flowers kecombrang (Nicolaia speciosa Horan) is an alternative natural preservative, because the content of bioactive components are alkaloids, polyphenols, flavonoids and atsiric oil. Penelitian aims to determine the effect of immersion beef in kecombrang (Etlingera elatior) flower extract on cooking loss, $\mathrm{pH}$ and Organoleptic. This research used complete Random Design (CRD) with 5 treatment and 4 replications. The treatments were as follows: P0 $=200 \mathrm{~g}$ beef (without treatment), $\mathrm{P} 1=200 \mathrm{~g}$ beef $+200 \mathrm{ml}$ distilled water $+10 \mathrm{ml}$ flower extracts kecombrang, $\mathrm{P} 2=200 \mathrm{~g}$ beef $+200 \mathrm{ml}$ distilled water $+20 \mathrm{ml}$ flower extracts kecombrang, $\mathrm{P} 3=200 \mathrm{~g}$ of meat cow $+200 \mathrm{ml}$ distilled water $+30 \mathrm{ml}$ kecombrang flower extract, $\mathrm{P} 4=200 \mathrm{~g}$ beef $+200 \mathrm{ml}$ distilled water +40 $\mathrm{ml}$ kecombrang flower extract. Variables include cooking loss, observational studies, $\mathrm{pH}$ and organoleptik. Based on the results of this study concluded that soaking the beef in kecombrang flower extracts (Etlingera elatior) between 10-40 $\mathrm{ml}$ can not be used to maintain the quality of beef but tend to increase the quality of beef quality in the old shelf life. Soaking beef with flower extracts kecombrang $40 \mathrm{ml}$ tends to give cooking loss, and the $\mathrm{pH}$ of the beef better on a long shelf life (cooking shrinkage $\mathrm{pH}$ from 33.70 to 46.54 and 5.25 to 6.08). The color and smell of soaking meat with flower extracts kecombrang had an odor, color and texture are better at long shelf life (ie, distinctive smell the smell of meat from 4.06 to $4.48,2.85$ to 3.84 the color of dark red color and 1.88-3.55 ie slightly soft). Beef with soaking kecombrang flower extract which is stored up to 12 hours still feasible for consumption.
\end{abstract}

Key word: Kecombrang flower, beef, cooking loss, pH, organoleptic

\begin{abstract}
ABSTRAK
Daging merupakan bahan makanan sumber protein hewani yang mudah mengalami kerusakan oleh karena aktivitas mikroorganisme perusak pangan. Bunga kecombrang (Nicolaia speciosa Horan) merupakan salah satu alternatif pengawet alami, karena kandungan komponen bioaktif yaitu alkaloid, polifenol, flavonoid dan minyak atsiri. Penelitian ini bertujuan untuk mengetahui pengaruh perendaman daging sapi dalam ekstrakbunga kecombrang (Etlingera elatior) terhadap susut masak, $\mathrm{pH}$ dan organoleptik. Penelitian menggunakan Rancangan Acak lengkap (RAL) terdir 5 perlakuan dengan 4 ulangan. Perlakuan yang diberikan sebagai berikut: $\mathrm{P} 0=200 \mathrm{~g}$ daging sapi (tanpa perlakuan), $\mathrm{P} 1=200 \mathrm{~g}$ daging sapi $+200 \mathrm{ml}$ aquades $+10 \mathrm{ml}$ ekstrak bunga kecombrang, $\mathrm{P} 2=200 \mathrm{~g}$ daging sapi $+200 \mathrm{ml}$ aquades $+20 \mathrm{ml}$ ekstrak bunga kecombrang, $\mathrm{P} 3=200 \mathrm{~g}$ daging sapi $+200 \mathrm{ml}$ aquades $+30 \mathrm{ml}$ ekstrak bunga kecombrang, $\mathrm{P} 4=200 \mathrm{~g}$ daging sapi $+200 \mathrm{ml}$ aquades $+40 \mathrm{ml}$ ekstrak bunga kecombrang. Variabel pengamatan penelitian meliputi susut masak, $\mathrm{pH}$ dan organoleptik. Berdasarkan hasil penelitian dapat disimpulkan bahwa perendaman daging sapi dalam ekstrak bunga kecombrang (Etlingera elatior) antara 10-40 ml belum dapat digunakan untuk mempertahankan kualitas daging sapi namun cenderung meningkatkan angka kualitas daging sapi sapi pada masa simpan yang lama. Perendaman daging sapi dengan ekstrak bunga kecombrang $40 \mathrm{ml}$ cenderung menghasilkan nilai susust masak, dan $\mathrm{pH}$ daging sapi yang lebih baik pada masa simpan yang lama (susut masak 33,70-46,54 dan $\mathrm{pH}$ 5,25-6,08). Pada warna dan bau perendaman daging dengan ekstrak bunga kecombrang memiliki bau, warna dan tekstur yang lebih baik pada masa simpan yang lama (bau 4,06-4,48 yakni berbau khas daging, warna 2,85-3,84 yakni warna merah gelap dan 1,88-3,55 yakni agak lembek). Daging sapi dengan perendaman ekstrak bunga kecombrang yang disimpan sampai dengan 12 jam masih layak untuk dikonsumsi.
\end{abstract}

Kata Kunci : bunga Kecombrang, daging sapi, susut masak, pH, organoleptik 


\section{PENDAHULUAN}

Daging dapat dibagi dalam dua kelompok yaitu daging segar dan daging olahan. Daging segar ialah daging yang belum mengalami pengolahan dan dapat dijadikan bahan baku pengolahan pangan. Sedangkan daging olahan adalah daging yang diperoleh dari hasil pengolahan dengan metode tertentu dengan atau tanpa bahan tambahan, misalnya sosis, dendeng, daging burger dan daging olahan dalam kaleng dan sebagainya (Desroiser, 1988).

Kontaminasi bakteri dapat menyebabkan perubahan warna dan bau. Selama proses memasak, warna daging dapat mengalami perubahan dan kurang menarik (Putra, 2008). Warna daging segar adalah warna merah terang dari oksimioglobin, warna daging yang dimasak adalah warna coklat dari globin hemikromogen, warna daging yang ditambahkan nitrit adalah warna merah gelap dari nitrikoksida mioglobin dan bila dimasak (Soeparno, 2005). Daging sapi yang dijual di pasar seringkali terkontaminasi oleh bakteri mesofilik (bakteri yang dapat tumbuh pada suhu 25$40^{\circ} \mathrm{C}$ ), karena proses penyiapan daging di pasar kurang memperhatikan aspek sanitasi dan hygiene, misalnya daging tidak ditutup dan penyimpanan hanya dalam suhu kamar, sehingga bakteri tumbuh dengan cepat (Suardana et al., 2007). Dijelaskan oleh Gustiani (2009), bakteri yang dapat mencemari daging antara lain Salmonella sp., E. coli, Coliform, Staphylococcus sp., dan Pseudomonas. Bakteri dalam daging segar dapat menyebabkan umur simpan daging menjadi lebih singkat (Takasari, 2008).

Daging dan ikan merupakan bahan makanan sumber protein hewani yang mudah mengalami kerusakan oleh aktivitas mikroorganisme perusak pangan. Mikrobia perusak pangan diantaranya adalah Staphylococcus aureus, Bacillus subtilis, Bacillus cereus Pseudomonad, Stafilococcus, Micrococcus, dan Enterococcus (Fardiaz, 1995). Upaya pengawetan perlu dilakukan agar pangan aman dan layak dikonsumsi. Pengawetan dapat dilakukan dengan pendinginan, penambahan zat kimia, iradiasi, dll. Usaha pengawetan diatur oleh undang-undang yaitu SK Menkes RI No. 722 tahun 1988 yang menegaskan bahwa pengawetan makanan diperbolehkan asal memenuhi peraturan yang ditetapkan. Pada peraturan tersebut juga dinyatakan bahwa penggunaan formalin di dalam makanan dilarang karena pertimbangan faktor keamanan dan kesehatan konsumen (Depkes-RI, 2006).

Mengingat akan bahaya penggunaan formalin tersebut maka perlu usaha untuk menemukan bahan pengawet dari bahan yang alami. Hasil beberapa penelitian menunjukkan bahwa rempahrempah dan bumbu asli Indonesia ternyata banyak mengandung zat aktif anti mikrobia yang berpotensi untuk dijadikan sebagai pengawet alami. Diantaranya adalah lengkuas, kunyit dan jahe. Kandungan minyak atsiri pada lengkuas dan jahe telah dibuktikan mempunyai sifat anti mikrobia (Taecho et al. 2004). Salah satu bahan tambahan pada sayuran yaitu 
bunga kecombrang juga dapat digunakan sebagai bahan pengawet makanan. Menurut Naufalin (2005), bunga Kecombrang (Nicolaia speciosa Horan) merupakan salah satu alternatif pengawet alami, karena kandungan komponen bioaktif yaitu alkaloid, polifenol, flavonoid dan minyak atsiri.

Hasil penelitian Naufalin (2005) tentang potensi bunga kecombrang sebagai pengawet alami pada tahu dan ikan, membuktikan bahwa bunga kecombrang dapat mempertahankan sifat mikrobiologi tahu selama 72 jam atau 3 hari pada suhu refrigerator. Serta mampu mempertahankan sifat fisik dan sifat mikrobiologi ikan nila selama 5 hari pada suhu refrigerator. Berdasarkan hal tersebut maka perlu dilakukan penelitian tentang susut masak, uji $\mathrm{pH}$ dan organoleptik daging sapi setelah direndam dalam larutan bunga kecombrang (Etlingera elatior). Penelitian ini bertujuan untuk mengetahui pengaruh perendaman daging sapi dalam ekstrak bunga kecombrang (Etlingera elatior) terhadap susut masak, $\mathrm{pH}$ dan organoleptik. Diduga perendaman daging sapi dalam ekstrak bunga kecombrang (Etlingera elatior) dapat mempertahankan kualitas daging sapi pada masa simpan yang lama.

\section{MATERI DAN METODE}

Penelitian ini telah dilaksanakan di Laboratorium Jurusan Peternakan Fakultas Pertanian Universitas Bengkulu. Bahan yang digunakan dalam penelitian adalah daging sapi, bunga kecombrang (Etlingera elatior), aquades. Alat -alat yang digunakan dalam penelitian $\mathrm{pH}$ meter, timbangan analitik, termometer, gelas ukur, belender, karter, nampan, baskom plastik, plastik PE (Polyethylen), box steroform, pisau dapur, sendok, tabung reaksi.

\section{Pemilihan Daging Sapi dan Bunga Kecombrang}

Daging sapi yang digunakan dalam penelitian daging bagian paha, diambil dari Rumah Potong Hewan Kota Bengkulu sebanyak $5 \mathrm{~kg}$ dan Bunga kecombrang yang digunakan Bunga kecombrang berwarna merah muda dan belum mekar sempurna, diperoleh dari pasar Tradisional di Kota Bengkulu sebanyak $3 \mathrm{~kg}$.

\section{Persiapan Bahan untuk Ekstraksi}

Tahap selanjutnya sebelum melakukan penelitian adalah mempersiapkan ekstrak bunga kecombrang. Ekstrak bunga dihasilkan melalui ekstraksi menggunakan metode maserasi. Bahan bunga kecombrang diseleksi terlebih dahulu dan diambil helaian mahkota bunganya lalu dicuci dengan air, kemudian helaian mahkota bunga kecombrang dikering anginkan sampai kering. Selanjutnya helaian bunga kering digiling, hasil gilingan bungga kecombrang kemudian direbus pada suhu $90^{\circ} \mathrm{C}$ dengan perbandingan bunga kecombrang dan air $1: 5$. Perebusan dilakukan selama 20 menit kemudian disaring. Ekstraksi dilakukan dua kali. Hasil saringan kemudian direbus kembali pada suhu $60^{\circ} \mathrm{C}$ sampai ekstrak berbentuk gel. 


\section{Tahapan Persiapan Daging}

Tahapan persiapan daging diawali dengan pembelian $5 \mathrm{~kg}$ daging sapi di Rumah Potong Hewan Kota Bengkulu. Setelah itu tahap persiapan yang dilakukan yakni dengann membungkus setiap potong daging sapi dalam plastik steril dan menyimpannya di dalam box stirofrom telah berisi es, digunakan untuk mempertahankan suhu daging sapi. Daging sapi yang digunakan dalam penelitian ini sebanyak $4 \mathrm{~kg}$ yakni untuk 5 perlakuan. Sebanyak 200g daging sapi digunakan untuk setiap perlakuan.

\section{Tahap Perendaman Daging}

Pada tahap perendaman ini daging sapi direndam dengan air $200 \mathrm{ml}$ dan ekstrak bunga kecombrang sesuai perlakuan $(\mathrm{P} 0=$ tanpa perlakuan, $\mathrm{P} 1=10$ $\mathrm{ml}, \mathrm{P} 2=20 \mathrm{ml}, \mathrm{P} 3=30 \mathrm{ml}, \mathrm{P} 4=40 \mathrm{ml}$ ) selama 30 menit. Waktu perendaman 30 menit merupakan waktu yang optimal untuk merendam daging karena tidak merusak tekstur, bau, dan penampakan, dengan nilai fisik, kimia masih di atas nilai yang ditetapkan Badan Standarisasi Nasional (Barus 2009). Setiap 200g daging sapi yang sudah direndam, ditiriskan selama 15 menit setelah itu didiamkan dengan menggunakan wadah nampan dan kemudian disimpan pada suhu ruang menggunakan plastic polyethylen. Kemudian dilakukan pengamatan sesuai dengan paremeter yang diamati.

\section{Rancangan Penelitian}

Penelitian

menggunakan

Rancangan Acak lengkap (RAL) terdiri 5 perlakuan dengan 4 ulangan. Perlakuan yang diberikan sebagai berikut:

$\mathrm{P} 0=200 \mathrm{~g}$ daging sapi (tanpa perlakuan)

$\mathrm{P} 1=200 \mathrm{~g}$ daging sapi $+200 \mathrm{ml}$ aquades +

$10 \mathrm{ml}$ ekstrak bunga kecombrang

$\mathrm{P} 2=200 \mathrm{~g}$ daging sapi $+200 \mathrm{ml}$ aquades + $20 \mathrm{ml}$ ekstrak bunga kecombrang $\mathrm{P} 3=200 \mathrm{~g}$ daging sapi $+200 \mathrm{ml}$ aquades + $30 \mathrm{ml}$ ekstrak bunga kecombrang $\mathrm{P} 4=200 \mathrm{~g}$ daging sapi $+200 \mathrm{ml}$ aquades + $40 \mathrm{ml}$ ekstrak bunga kecombrang

Metode analisis data yang dipergunakan untuk menarik kesimpulan hasil penelitian adalah dengan metoda Rancangan Acak Lengkap ( RAL) (Steel danTorrie, 1993)

$$
Y \mathbf{i j}=\boldsymbol{\mu}+\boldsymbol{\beta i}+\mathbf{\varepsilon i j}
$$

Yij = Nilai pengamatan pada perlakuan kei dan ulangan ke-j

$\mu=$ Nilai Rataan umum dari perlakuan

$\beta \mathrm{i}=$ pengaruh perlakuan ke- $\mathrm{i}$

$\varepsilon i j=$ Galat pada perlakuan ke-i dan ulangan ke-j.

Variabel penelitian, pengukuran susut masak. Cara pengukuran susut masak menurut (Soeparno, 2005). Sampel daging dipotong ukurn $2 \times 2 \times 2 \mathrm{~cm}$, ditimbang kemudian dimasukkan ke dalam plastik polietilen dan ditutup rapat agar pada saat perebusan air tidak dapat masuk ke dalam kantong plastik, kemudian sampel direbus dalam waterbath pada suhu $80^{\circ} \mathrm{C}$ selama satu jam. Setelah perebusan sampel daging didinginkan dengan memasukkan ke dalam beaker glass yang berisi air dingin dengan temperatur $10^{\circ} \mathrm{C}$, 
selama 15 menit, kemudin sampel dikeluarkan dari kantong plastik dan dikeringkan dengan kertas saring dan dilakukan penimbangan kembali. Pengukuran susut masak dilakukan pada 0 jam, 6 jam, 18 jam 24 jam dan 30 jam. Susut masak dihitung menggunakan rumus:

$S M(\%)=\frac{\text { Berat awal }- \text { Berat akhir }}{\text { Berat Awal }} \times 100$

Pengukuran $\mathrm{pH}$, cara pengukuran pH menurut (AOAC 1995). Sebanyak 10 gram sampel dihancurkan terlebih dahulu dengan menggunakan alat homogenizer dan selanjutnya dihomogenisasikan dengan $90 \mathrm{ml}$ aquades. Larutan homogen tersebut diukur dengan $\mathrm{pH}$ meter yang sudah dikalibrasi dengan larutan buffer standar ( $\mathrm{pH} 4$ dan 7). Pengukuran nilai $\mathrm{pH}$ dilakukan pada 0 jam, 6 jam, 18 jam 24 jam dan 30 jam penyimpanan.

Pengujian organoleptik dilakukan oleh panelis standar yang terlibat untuk satu kali pengujian adalah 15 orang . Penilaian indrawi ini dilakukant terhadap beberapa parameter uji, yaitu parameter penampakan, warna, bau, dan tekstur. sampel diuji secara acak dengan memberikan kode pada sampel yang akan diuji. Potongan daging sapi yang diuji secara organoleptik diberi nilai berdasarkan penilaian penelis dan dituangkan dalam lembaran scoresheet (penilaian) Penilaian organoleptik dilakukan pada 0 jam, 6 jam, 12 jam, 18 jam, 24 jam dan 30 jam. dalam skala 1 (satu) sebagai nilai terendah dan angka 5 (lima) sebagai nilai tertinggi. Adapun kriteria penilaian uji organoleptik dapat dilihat pada Tabel 1. dibawah ini.

Tabel 1. Kriteria uji organoleptik

\begin{tabular}{llll}
\hline Warna & Bau & Tekstur & Skor \\
\hline Merah coklat & Sangat berbau busuk & Lembek & 1 \\
Merah kecoklatan & Berbau busuk & Agak lembek & 2 \\
Merah Gelap & Agak berbau busuk & Agak empuk & 3 \\
Agak merah gelap & Berbau khas daging & Empuk & 4 \\
Merah cerah & Sangat berbau khas daging & Sangat empuk & 5 \\
\hline
\end{tabular}

Data yang diproleh akan dianalisis dengan sidik ragam ( ANOVA). Apa bila terdapat perbedaan nyata dilakuakan uji lanjut dengan menggunakan Duncan's multiple Range Test (DMRT).

\section{HASIL DAN PEMBAHASAN}

\section{Rataan Susut Masak Daging Sapi}

Rataan susut masak daging sapi yang tidak dilakukan perlakuan (P0), setelah perendaman daging dalam 10, 20, 30, dan $40 \mathrm{ml}$ ekstrak bungga kecombrang penyimpanan $0,6,12,18,24$, dan 30 jam disajikan pada tabel 2. Hasil analisis ragam menunjukkan bahwa perendaman daging sapi dalam ekstrak bunga kecombrang tidak berbeda nyata $(\mathrm{P}>0,05)$ terhadap susut masak daging sapi. 
Tabel 2. Rataan persentase susut masak daging sapi setiap perlakuan selama penyimpanan 0 , $6,12,18,24$, dan 30 jam.

\begin{tabular}{|c|c|c|c|c|c|c|}
\hline \multirow{2}{*}{$\begin{array}{c}\text { Waktu } \\
\text { Pengamatan }\end{array}$} & \multicolumn{5}{|c|}{ Perlakuan } & \multirow[b]{2}{*}{$\mathrm{P}$} \\
\hline & P0 & P1 & $\mathrm{P} 2$ & P3 & $\mathrm{P} 4$ & \\
\hline 0 Jam & $37,97 \pm 4,40$ & $37,46 \pm 6,44$ & $34,52 \pm 3,12$ & $33,84 \pm 7,07$ & $33,70 \pm 2,43$ & ns \\
\hline $6 \mathrm{Jam}$ & $39,51 \pm 5,90$ & $41,70 \pm 5,22$ & $38,61 \pm 5,87$ & $38,61 \pm 4,37$ & $37,95 \pm 5,87$ & ns \\
\hline 12 Jam & $43,21 \pm 3,28$ & $43,02 \pm 3,71$ & $43,07 \pm 10,10$ & $39,39 \pm 2,94$ & $38,72 \pm 6,56$ & ns \\
\hline $18 \mathrm{Jam}$ & $45,88 \pm 5,22$ & $44,26 \pm 1,85$ & $44,44 \pm 3,83$ & $43,79 \pm 2,78$ & $41,70 \pm 5,48$ & ns \\
\hline 24 Jam & $47,40 \pm 6,72$ & $45,09 \pm 2,04$ & $45,64 \pm 3,26$ & $47,34 \pm 3,79$ & $42,76 \pm 2,35$ & ns \\
\hline $30 \mathrm{Jam}$ & $52,30 \pm 6,43$ & $51,22 \pm 2,40$ & $48,23 \pm 2,59$ & $49,02 \pm 12,29$ & $46,54 \pm 1,96$ & $\mathrm{~ns}$ \\
\hline
\end{tabular}

Ket : P0 : $200 \mathrm{~g}$ daging sapi (tanpa perlakuan), P1: $200 \mathrm{~g}$ daging sapi $+200 \mathrm{ml}$ aquades $+10 \mathrm{ml}$ ekstrak bunga kecombrang, P2 : $200 \mathrm{~g}$ daging sapi $+200 \mathrm{ml}$ aquades $+20 \mathrm{ml}$ ekstrak bunga kecombrang, P3: $200 \mathrm{~g}$ daging sapi $+200 \mathrm{ml}$ aquades $+30 \mathrm{ml}$ ekstrak bunga kecombrang, $\mathrm{P} 4: 200 \mathrm{~g}$ daging sapi $+200 \mathrm{ml}$ aquades + $40 \mathrm{ml}$ ekstrak bunga kecombrang. Notasi ns untuk baris yang sama memperlihatkan antar perlakuan tidak berbeda nyata $(\mathrm{P}>0,05)$.

Hasil penelitian diperoleh rataan susut masak terendah pada waktu pengamatan $0,6,12,18,24$ dan 30 jam adalah P4 sebesar 33,70\%, 37,95\%, $38,72 \%, 41,70 \%, 42,76 \%$ dan $46,54 \%$, hasil ini menunjukkan bahwa ekstrak bunga kecombrang sebesar $40 \mathrm{ml}$ memiliki nilai susut masak paling bagus. Hasil penelitian ini sesuai dengan pernyataan Soeparno (2005), yang menyatakan bahwa daging yang memiliki kualitas yang baik adalah daging dengan susut masak terendah, karena tidak banyak kehilangan nutrisi selama pemasakan. Yanti et al. (2008), menyatakan daging yang mempunyai angka susut masak rendah, memiliki kualitas yang baik karena kemungkinan keluarnya nutrisi daging selama pemasakan juga rendah.

Pada umumnya nilai susut masak daging sapi yang normal menurut Lawrie (2003), berkisar antara 1,5-54,5\%. Nilai susut masak pada hasil penelitian pada semua perlakuan sampai masa simpan 30 jam masih dalam kisaan normal karena berkisar antara 33,70-52,30\%. Pada hasil penelitian juga dapat dilihat bahwa persentase susut masak daging sapi semakin lama penyimpanan maka nilai semakin meningkat.

\section{Rataan pH Daging Sapi}

Rataan nilai $\mathrm{pH}$ daging sapi yang tidak dilakukan perlakuan (P0), setelah perendaman daging dalam 10, 20, 30, dan $40 \mathrm{ml}$ ekstrak bungga kecombrang penyimpanan $0,6,12,18,24$, dan 30 jam disajikan pada tabel 3.

Hasil analisis ragam menunjukkan bahwa perendaman ekstrak bunga kecombrang dengan konsentrasi yang berbeda tidak berbeda nyata terhadap pHdaging sapi $(\mathrm{P}>0,05)$ pada waktu pengamatan $0,12,18,24$, dan 30 jam, namun berbeda nyata terhadap pHdaging sapi $(\mathrm{P}<0,05)$ pada waktu pengamatan 6 jam penyimpanan. Tabel 2. memperlihatkan bahwa rataan nilai $\mathrm{pH}$ daging sapi terendah pada waktu pengamatan 0,6 , dan 12 jam adalah P4 sebesar 5,25, 5,36, dan 5,83, hasil ini menunjukkan bahwa penambahan ekstrak bunga kecombrang sebesar $40 \mathrm{ml}$ dapat mempertahankan nilai $\mathrm{pH}$ daging sapi. 
Tabel 3. Rataan $\mathrm{pH}$ daging sapi setiap perlakuan selama penyimpanan $0,6,12,18,24$, dan 30 jam.

\begin{tabular}{ccccccc}
\hline Waktu & \multicolumn{5}{c}{ Perlakuan } & \multirow{2}{*}{ P } \\
\cline { 2 - 6 } Pengamatan & $\mathrm{P} 0$ & $\mathrm{P} 1$ & $\mathrm{P} 2$ & $\mathrm{P} 3$ & $\mathrm{P} 4$ & $\mathrm{~ns}$ \\
\hline 0 Jam & $5,54 \pm 0,52$ & $5,37 \pm 0,44$ & $5,28 \pm 0,70$ & $5,26 \pm 0,65$ & $5,25 \pm 0,43$ & $\mathrm{Ns}$ \\
6 Jam & $5,75 \pm 0,14$ & $5,77 \pm 0,13$ & $5,84 \pm 0,07$ & $5,84 \pm 0,05$ & $5,85 \pm 0,13$ & Ns \\
12 Jam & $5,86 \pm 0,10$ & $5,84 \pm 0,11$ & $5,86 \pm 0,03$ & $5,91 \pm 0,24$ & $5,83 \pm 008$ & Ns \\
18 Jam & $6,06 \pm 0,05$ & $6,02 \pm 0,13$ & $6,06 \pm 0,20$ & $5,95 \pm 0,05$ & $5,96 \pm 0,39$ & Ns \\
24 Jam & $6,28 \pm 0,30$ & $6,06 \pm 0,20$ & $6,16 \pm 0,29$ & $6,08 \pm 0,19$ & $5,96 \pm 0,29$ & Ns \\
30 Jam & $6,36 \pm 0,14$ & $6,11 \pm 0,38$ & $6,30 \pm 0,30$ & $6,26 \pm 0,17$ & $6,08 \pm 0,08$ & Ns \\
\hline
\end{tabular}

Ket : P0 : $200 \mathrm{~g}$ daging sapi (tanpa perlakuan), P1: $200 \mathrm{~g}$ daging sapi $+200 \mathrm{ml}$ aquades $+10 \mathrm{ml}$ ekstrak bunga kecombrang, P2 : $200 \mathrm{~g}$ daging sapi $+200 \mathrm{ml}$ aquades $+20 \mathrm{ml}$ ekstrak bunga kecombrang, P3: $200 \mathrm{~g}$ daging sapi $+200 \mathrm{ml}$ aquades $+30 \mathrm{ml}$ ekstrak bunga kecombrang, P4 : $200 \mathrm{~g}$ daging sapi $+200 \mathrm{ml}$ aquades + $40 \mathrm{ml}$ ekstrak bunga kecombrang. Superskrip yang berbeda pada baris yang sama menunjukkan perbedaan yang nyata $(\mathrm{P}<0,05)$.Notasi ns untuk baris yang sama memperlihatkan antar perlakuan tidak berbeda nyata $(\mathrm{P}>0,05)$.

Hasil penelitian juga menunjukkan penggunaan ekstrak daun kecombrang hingga $40 \mathrm{ml}$ (P4) lebih baik dari pada perlakuan tanpa menggunakan ekstrak daun kecombrang (P0). Hal ini diduga disebabkan oleh penambahan ekstrak bunga kecombrang dapat mempertahankan sifat mikrobiologi daging sapi. Hasil penelitian ini serupa dengan hasil penelitian Naufalin (2005), yang membuktikan bahwa bunga kecombrang dapat mempertahankan sifat mikrobiologi tahu selama 72 jam atau 3 hari pada suhu refrigerator. Serta mampu mempertahankan sifat fisik dan sifat mikrobiologi ikan nila selama 5 hari, pengamatan dan pengukuran dilakukan terhadap tahu yang disimpan selama $0,1,2$ dan 3 hari yang direndam bubur bunga kecombrang, sedangkan pada ikan dilakukan pengamatan pada 0, 510 dan 15 hari pada suhu refrigerator.

Kisaran nilai $\mathrm{pH}$ daging yang diamati pada 0 jam sampai dengan 12 jam masih bagus yakni sebesar 5,28-5,91.
Sedangkan nilai $\mathrm{pH}$ daging sapi pada waktu 18 jam sampai dengan 30 jam sudah tidak bagus karena mendekati $\mathrm{pH}$ netral. Hasil penelitian ini sesuai dengan Siagian (2002), yang menyatakan bahwa bahan makanan dengan $\mathrm{pH}$ mendekati netral jumlah mikroba jenis bakteri lebih banyak dibandingkan dengan mikroba jenis lainnya. Pertumbuhan mikroba ini akan terus berlangsung dan akan dicapai $\mathrm{pH}$ ideal untuk pertumbuhan mikroba, yaitu pada $\mathrm{pH}$ netral karena sebagaian besar bakteri akan tumbuh pada $\mathrm{pH}$ netral (Forrestet al, 1975, Levie, 1977), Hal yang sama dikemukakan Jay (1978), bahwa pH ideal untuk bakteri adalah pada kisaran $\mathrm{pH}$ 6,6 sampai 7,5. Menurut Soeparno (2005), $\mathrm{pH}$ normal daging adalah sekitar 5,3 sampai 5,8. Tabel 2. juga memperlihatkan bahwa semakin lama penyimpanan maka semakin tinggi $\mathrm{pH}$ daging sapi. Menurut Suardi (2012), daging yang disimpan pada suhu kamar selama 12 jam sudah mendekati kebusukan, dan penyimpanan selama $\quad 18 \quad$ jam sudah 
dinyatakan busuk. Hasil penelitian ini lebih baik karena daging mendekati busuk atau tidak bisa lagi digunakan setelah 18 jam penyimpanan pada suhu ruangan. Menurut Thornton (1957), bahwa jika pH daging mencapai 6,8 atau lebih tinggi akan terjadidekomposisi protein yang nyata, yaitu teradi perubahan bau, warna dan tekstur.

Faktor lain yang mengakibatkan peningkatan $\mathrm{pH}$ adalah umur dari sapi yang sudah tuadan juga dapat terjadi akibat pertumbuhan mikroorganisme. Nilai $\mathrm{pH}$ daging sapi setelah perubahan glikolisis menjadi asam laktat berhenti berkisar antara 5,1-6,2 (Buckle et al., 1987). Nilai $\mathrm{pH}$ juga berpengaruh terhadap keempukan daging. Daging dengan $\mathrm{pH}$ tinggi mempunyai keempukan yang lebih tinggi daripada daging dengan $\mathrm{pH}$ rendah. Kealotan atau keempukan serabut otot pada kisaran pH 5,4 sampai 6,0 lebih banyak ditentukan oleh status kontraksi serabut otot dari pada oleh status fisik serabut otot (Bouton et al., 1986).Soeparno (2005), menyatakan bahwa faktor ekstrinstik seperti temperatur, kelembaban dan stres, serta faktor intrinstik seperti spesies, bangsa, jenis kelamin, individu ternak, macam otot daging, aktivitas otot, dan aktivitas enzim-enzim glikolisis dapat mempengaruhi $\mathrm{pH}$ otot postmortem. Nilai pH juga memiliki hubungan dengan nilai daya mengikat air (DMA).

\section{Uji Organoleptik}

Rataan nilai uji organoleptik bau, warna, dan tekstur daging sapi yang tidak dilakukan perlakuan (P0), setelah perendaman daging dalam 10, 20, 30, dan $40 \mathrm{ml}$ ekstrak bungga kecombrang penyimpanan $0,6,12,18,24$, dan 30 jam disajikan pada tabel 4 .

Tabel 4. Rataan nilai uji organoleptik bau daging sapi setiap perlakuan selama penyimpanan 0-30 jam.

\begin{tabular}{ccccccc}
\hline Waktu & \multicolumn{5}{c}{ Perlakuan } & \multirow{2}{*}{ P } \\
\cline { 2 - 6 } Pengamatan & P0 & P1 & P2 & P3 & P4 & Ns \\
\cline { 2 - 6 } 0 Jam & $4,41 \pm 0,23$ & $4,38 \pm 0,42$ & $4,31 \pm 0,22$ & $4,34 \pm 0,14$ & $4,48 \pm 0,17$ & Ns \\
6 Jam & $4,22 \pm 0,18$ & $4,37 \pm 0,17$ & $4,27 \pm 0,18$ & $4,30 \pm 0,08$ & $4,31 \pm 0,24$ & Ns \\
12 Jam & $3,91 \pm 0,13$ & $4,06 \pm 0,34$ & $4,13 \pm 0,09$ & $4,10 \pm 0,21$ & $4,21 \pm 0,30$ & Ns \\
18 Jam & $3,45 \pm 0,20$ & $3,42 \pm 0,22$ & $3,47 \pm 0,46$ & $3,37 \pm 0,31$ & $3,40 \pm 0,24$ & Ns \\
24 Jam & $3,08 \pm 0,43$ & $3,13 \pm 0,14$ & $3,16 \pm 0,15$ & $3,13 \pm 0,69$ & $3,13 \pm 0,45$ & Ns \\
30 Jam & $2,94 \pm 0,11$ & $2,81 \pm 0,10$ & $2,55 \pm 0,41$ & $2,44 \pm 0,40$ & $2,43 \pm 0,23$ & .
\end{tabular}

Ket : P0 : $200 \mathrm{~g}$ daging sapi (tanpa perlakuan), P1: 200g daging sapi $+200 \mathrm{ml}$ aquades $+10 \mathrm{ml}$ ekstrak bunga kecombrang, P2 : 200g daging sapi $+200 \mathrm{ml}$ aquades $+20 \mathrm{ml}$ ekstrak bunga kecombrang, P3 : $200 \mathrm{~g}$ daging sapi $+200 \mathrm{ml}$ aquades $+30 \mathrm{ml}$ ekstrak bunga kecombrang, $\mathrm{P} 4: 200 \mathrm{~g}$ daging sapi $+200 \mathrm{ml}$ aquades + $40 \mathrm{ml}$ ekstrak bunga kecombrang. Notasi ns untuk baris yang sama memperlihatkan antar perlakuan tidak berbeda nyata $(\mathrm{P}>0,05)$.

Hasil analisis ragam menunjukkan perendaman ekstrak bunga kecombrang tidak berbeda nyata $(\mathrm{P}>0,05)$ terhadap organoleptik baudaging sapi. Hasil penelitian menunjukkan bahwa bau daging sapi pada pengamatan 0-12 jam keadaan 
daging sapi masih berbau khas daging yakni berasa pada kisaran 3,91-4,48. Sedangkan daging sapi pada pengamatan 18-30 jam keadaan daging sapi sudah agak berbau busuk bahkan cenderung berbau busuk. Faktor yang mempengaruhi rasa adalah aroma yang terdeteksi oleh hidung. Menurut Trantono (2011), aroma pada daging sapi dipengaruhi oleh jenis pakan yang diberikan pada saat sapi hidup. Aroma yang tidak normal biasanya akan segera tercium sesudah hewan dipotong. Hal itu dapat disebabkan oleh adanya kelainan antara lain hewan sakit dan hewan dalam pengobatan. Hewan yang sakit, terutama yang menderita radang bersifat akut pada organ dalam, akan menghasilkan daging yang berbau seperti mentega tengik. Hewan dalam masa pengobatan terutama dengan pemberian antibiotika, akan menghasilkan daging yang berbau obatobatan.Evaluasi bau sangat terggantung pada panel cita rasa (Soeparno, 2005). Menurut Winarno et al., (2002), bau menentukan kelezatan bahan makanan. Menurut Zuhra (2006), indera penciuman yaitu hidung memiliki kemampuan yang terbatas.

Tabel 5. Rataan nilai uji organoleptik warna daging sapi setiap perlakuan selama penyimpanan 0-30 jam.

\begin{tabular}{ccccccc}
\hline Waktu & \multicolumn{5}{c}{ Perlakuan } & \multirow{2}{*}{ P } \\
\cline { 2 - 6 } Pengamatan & P0 & P1 & P2 & P3 & P4 & Ns \\
\cline { 2 - 6 } 0 Jam & $3,99 \pm 0,24$ & $3,70 \pm 0,26$ & $3,70 \pm 0,74$ & $3,90 \pm 0,42$ & $3,84 \pm 0,26$ & Ns \\
6 Jam & $3,18 \pm 0,69$ & $3,37 \pm 0,19$ & $2,60 \pm 0,94$ & $3,07 \pm 0,87$ & $3,58 \pm 0,65$ & Ns \\
12 Jam & $2,58 \pm 0,72$ & $2,73 \pm 0,27$ & $2,05 \pm 0,15$ & $2,37 \pm 0,26$ & $2,85 \pm 0,58$ & Ns \\
18 Jam & $2,30 \pm 0,33^{\text {a }}$ & $2,58 \pm 0,47^{\text {a }}$ & $2,37 \pm 0,12^{\text {b }}$ & $2,40 \pm 0,37^{\text {a }}$ & $2,57 \pm 0,20^{\text {a }}$ & Ns \\
24 Jam & $2,00 \pm 0,40$ & $2,13 \pm 0,05$ & $1,68 \pm 0,41$ & $1,70 \pm 0,16$ & $2,07 \pm 0,09$ & Ns \\
30 Jam & $1,58 \pm 0,38$ & $1,62 \pm 0,31$ & $1,55 \pm 0,08$ & $1,70 \pm 0,27$ & $1,77 \pm 0,30$ & Ns \\
\hline
\end{tabular}

Ket : P0 : 200g daging sapi (tanpa perlakuan), P1: $200 \mathrm{~g}$ daging sapi $+200 \mathrm{ml}$ aquades $+10 \mathrm{ml}$ ekstrak bunga kecombrang, P2 : $200 \mathrm{~g}$ daging sapi $+200 \mathrm{ml}$ aquades $+20 \mathrm{ml}$ ekstrak bunga kecombrang, P3 : $200 \mathrm{~g}$ daging sapi $+200 \mathrm{ml}$ aquades $+30 \mathrm{ml}$ ekstrak bunga kecombrang, $\mathrm{P} 4: 200 \mathrm{~g}$ daging sapi $+200 \mathrm{ml}$ aquades $+40 \mathrm{ml}$ ekstrak bunga kecombrang. Superskrip yang berbeda pada baris yang sama menunjukkan perbedaan yang nyata $(\mathrm{P}<0,05)$.Notasi ns untuk baris yang sama memperlihatkan antar perlakuan tidak berbeda nyata $(\mathrm{P}>0,05)$.

Hasil analisis ragam menunjukkan perendaman ekstrak bunga kecombrang tidak berbeda nyata $(\mathrm{P}>0,05)$ terhadap uji organoleptik warna daging sapi pada waktu pengamatan $0,6,12,18,24$ dan 30 jam. Kisaran hasil rataan warna daging sapi pada pengamatan 0-6 jam agak merah gelap cenderung ke merah gelap, pada pengamatan 12-18 jamdaging sapi berwarna merah gelap cenderung merah kecoklatan. Daging sapi pada pengamatan 24-30 jam berwarna merah kecokelatan cenderung merah cokelat. Menurut Soeparno (2005), bahwa penentu utama warna daging adalah konsentrasi mioglobin dan hemoglobin, dimana mioglobin berbeda di antara otot (merah dan putih), umur, spesies, bangsa dan lokasi otot. Menurut Trantono (2011), ada beberapa faktor yang mempengaruhi 
warna daging mentah. Beberapa faktor tersebut adalah spesies, usia, jenis kelamin hewan, cara memotong daging, waterholding (air yang dikandung) kapasitas daging, pengeringan pada permukaan daging, pembusukan pada permukaan daging, dan cahaya yang mengenai permukaan daging.

Hasil analisis ragam menunjukkan perendaman ekstrak bunga Kecombrang tidak berbeda nyata $(\mathrm{P}>0,05)$ terhadap uji organoleptik teksturdaging sapi. Pemberian perendaman ekstrak bunga Kecombrang pada daging sapi tidak mempengaruhi kesukaan tekstur daging sapi dengan penilaiann agak empuk bahkan cenderung agak lembek untuk pengamatan 0-12 jam, sedangkan pengamatan 18-30 jam daging agak lembek bahkan cenderung lembek.

Tabel 6. Rataan nilai uji organoleptik tekstur daging sapi setiap perlakuan selama penyimpanan 0-30 jam.

\begin{tabular}{ccccccc}
\hline Waktu & \multicolumn{5}{c}{ Perlakuan } & \multirow{2}{*}{ P } \\
\cline { 2 - 6 } Pengamatan & P0 & P1 & P2 & P3 & P4 & Ns \\
\cline { 2 - 6 } 0 Jam & $3,13 \pm 0,45$ & $3,35 \pm 0,28$ & $3,55 \pm 0,39$ & $3,43 \pm 0,26$ & $3,40 \pm 0,49$ & Ns \\
6 Jam & $3,12 \pm 0,30$ & $3,28 \pm 0,19$ & $3,23 \pm 0,14$ & $3,18 \pm 0,34$ & $3,12 \pm 0,51$ & Ns \\
12 Jam & $2,27 \pm 0,24$ & $2,00 \pm 0,11$ & $1,93 \pm 0,16$ & $1,87 \pm 0,26$ & $1,88 \pm 0,43$ & Ns \\
18 Jam & $1,92 \pm 0,26$ & $1,94 \pm 0,53$ & $1,88 \pm 0,57$ & $1,70 \pm 0,07$ & $1,87 \pm 0,43$ & Ns \\
24 Jam & $1,88 \pm 0,53$ & $1,83 \pm 0,63$ & $1,82 \pm 0,23$ & $1,62 \pm 0,42$ & $1,85 \pm 0,58$ & Ns \\
30 Jam & $1,77 \pm 0,21$ & $1,68 \pm 0,13$ & $1,82 \pm 0,19$ & $1,53 \pm 0,11$ & $1,80 \pm 0,45$ & .
\end{tabular}

Ket : P0 : $200 \mathrm{~g}$ daging sapi (tanpa perlakuan), P1: $200 \mathrm{~g}$ daging sapi $+200 \mathrm{ml}$ aquades $+10 \mathrm{ml}$ ekstrak bunga kecombrang, P2 : $200 \mathrm{~g}$ daging sapi $+200 \mathrm{ml}$ aquades $+20 \mathrm{ml}$ ekstrak bunga kecombrang, P3: $200 \mathrm{~g}$ daging sapi $+200 \mathrm{ml}$ aquades $+30 \mathrm{ml}$ ekstrak bunga kecombrang, $\mathrm{P} 4: 200 \mathrm{~g}$ daging sapi $+200 \mathrm{ml}$ aquades + $40 \mathrm{ml}$ ekstrak bunga kecombrang. Notasi ns untuk baris yang sama memperlihatkan antar perlakuan tidak berbeda nyata $(\mathrm{P}>0,05)$.

Menurut Triatmojo (1992), bahwa adonan yang emulsinya stabil akan menyebabkan tekstur yang lebih baik. Menurut Soeparno (2005), keempukan dan tekstur daging kemungkinan besar merupakan penentu yang paling penting pada kualitas daging. Faktor yang mempengaruhi keempukan daging digolongkan menjadi faktor antemortem seperti genetik dan termasuk bangsa, spesies dan fisiologi, faktor umur, managemen, jenis kelamin dan stress. Faktor postmortem antara lain meliputi metode pelayuan (chilling), refrigerasi dan pembekuan termasuk faktor lama dan temperatur penyimpanan serta metode pengolahan termasuk metode pemasakan dan penambahan bahan pengempuk. Jadi keempukan bisa bisa bervariasi diantaranya spesies, bangsa, ternak dalam spesies yang sama, potongan karkas dan diantara otot serta otot yang sama.

\section{KESIMPULAN}

Berdasarkan hasil penelitian dapat disimpulkan bahwa perendamanekstrak bunga Kecombrang pada daging sapi (Etlingera elatior) antara 10-40ml dilihat dari angka statistik belum dapat digunakan untuk mempertahankan kualitas daging 
sapi namun cendrung meningkatkan angka kualitas daging sapi sampai pengamatan 30 jam. Perendaman daging sapi dengan ekstrak bunga Kecombrang sebanyak 40 $\mathrm{ml}$ cenderung menghasilkan nilai susust masak, dan $\mathrm{pH}$ daging sapi yang lebih baik sampai masa simpan 30 jam (susut masak 33,70-46,54 dan pH 5,25-6,08).

Pada warna dan bau perendaman daging dengan ekstrak bunga Kecombrang memiliki bau, warna dan tekstur yang lebih baik pada masa simpan yang lama (bau 4,06-4,48 yakni berbau khas daging, warna 2,85-3,84 yakni warna merah gelap dan tekstur 1,88-3,55 yakni agak lembek). Daging sapi dengan perendaman ekstrak bunga Kecombrang yang disimpan sampai dengan 12 jam masih layak untuk dikonsumsi.

\section{DAFTAR PUSTAKA}

Barus, P. 2009. Pemanfaatan bahan pengawet dan antioksidan alami pada industri bahan makanan. Pidato Pengukuhan Jabatan Guru Besar Tetap dalam Bidang Ilmu Kimia Analitik pada Fakultas Matematika dan Ilmu Pengetahuan Alam, diucapkan di hadapan Rapat Terbuka Universitas Sumatera Utara. Universitas Sumatra Utara Medan.

Bouton, P.E., P.V. Harris and W.R. Shorthose. $1986 . \quad$ Factor Influencing Cooking Losses from Meat. J. Food Sci.

Buckle, K.A., R.A. Edwards,G.H. Fleet, dan M. Wootton. 1987. Ilmu
Pangan. Terjemahan: Hari

Purnomo Adiono. UI Press:

Jakarta.

Desroiser, N. W. (1988). Teknologi Pengawetan Pangan, terjemahan Mucji Muljohardjo, Universtas Indonesia, Jakarta.

Fardiaz, S. 1995. Mikrobiologi Pangan. Gramedia Press, Jakarta.

Forrest, J.C., E.D. Aberle, H.B. Hedrick, M.D. Judge, R.A. Merkel. 1975. Principles of Meat Science, W.H. Freeman and Co. San Francisco.

Gustiani, E. 2009. Pengendalian Cemaran Mikroba pada Bahan Pangan Asal Ternak (Daging dan Susu) Mulai dari Peternakan Sampai Dihidangkan. Jurnal Litbang Pertanian. 28:96-100.

Jay, J. M. 1978. Modern Food Microbiology, second Ed. Wayne State University, D. Van Nastrand Co, New York.

Lawrie, R. A. 2003. Ilmu Daging. Edisi Kelima. Penerjemah Aminuddin Parakkasi dan Yudha Amwila. Penerbit Universitas Indonesia (UI-Press), Jakarta.

Naufalin, R. 2005. Kajian Sifat Antimikroba Bunga Kecombrang (Nicolaia speciosa Horan) Terhadap Berbagai Mikroba Patogen dan Perusak Pangan. Disertasi. Pascasarjana, Institut Pertanian Bogor. 
Putra, R. P., (2008), Waspadai Pembentukan Nitrosamin pada Daging yang Diawetkan.

Siagian, A. 2002. Mikroba Patogen Pada Makanan dan Sumber Pencemarannya. Fakultas Kesehatan Masyarakat. USU. http://www.library.usu.ac.id. (Diakses pada tanggal 15 Oktober 2015).

Soeparno. 2005. Ilmu dan Teknologi Daging. Cetakan Ke-4. Gadjah Mada University Press, Yogyakarta.

Suardana, I. W., S. Bambang dan W. L. Denny. 2007. Isolasi dan Identifikasi Escherchia coli O157:H7 pada Daging Sapi di Kabupaten Badung Provinsi Bali. Jurnal Veteriner. 8:16-23.

Suardi, K. 2012. Pengaruh lama penyimpanan pada suhu ruang terhadap perubahan nilai $\mathrm{pH}$, TVB, dan total bakteri daging kerbau. Jurnal Imu Ternak. Vol 12. (2) : 9-12.

Taecho, W. T., Peberdy, J.F. dan Lumyong, S. (2004). Isolation of Endophytic Actinomycetes from Selected Plants and Their Antifugal Actifity. Depertemen of Biologi, Univercity of Nottingham, Thailand.

Takasari, C. 2008. Kualitas Mikrobiologis Daging Sapi Segar dengan
Penambahan Bakteriosin dari Lactobacillus sp. Galur SCG 1223 yang Diisolasi dari Susu Sapi. Skripsi. Fakultas Peternakan. Institut Pertanian Bogor.

Thornton, H. 1957. Text Book of Meat Inspection, 3 rd Ed. Bailliers Tindall and Cox, London.

Triatmojo, S. 1992. Pengaruh Pengantian Daging Sapi Dengan Daging Kerbau, Ayam Dan Kelinci Pada Komposisi Dan Kualitas Bakso. Laporan Penelitian Fakultas Peternakan, Universitas Gadjah Mada, Yogyakarta.

Winarno, F.G. 2002. Kimia Pangan dan Gizi. PT Gramedia Pustaka Utama. Jakarta.

Yanti, H., Hidayati, dan Elfawati. 2008. Kualitas daging sapi dengan kemasan plastik PE (polyethylen) dan plastik PP (polypropylen) Di pasar Arengka kota Pekanbaru. Jurnal Peternakan Vol 5 No (22 27)

Zuhra, C.F. 2006. Cita Rasa (Flavour). Fakultas Matematika dan Ilmu Pengetahuan Alam. Universitas Sumatra Utara. Medan. Kualitas Semen Produksi UPTD Bengkulu dan Tingkat Keberhasilan Inseminasi pada Sapi Bali dan Peranakan Simental di Bengkulu 